\title{
RESEARCH PAPER \\ Consumer preferences and willingness to pay for organic apples
}

\author{
Arcadio A. Cerda ${ }^{1}$, Leidy Y. García ${ }^{2}$, Samuel Ortega-Farías ${ }^{3}$, and Álvaro M. \\ Ubilla $^{1}$ \\ 'Facultad de Ciencias Empresariales, Universidad de Talca, 2 Norte 685. Talca, Chile. \\ ${ }^{2}$ Facultad de Ciencias Sociales y Económicas, Universidad Católica del Maule, Avda. San Miguel 3605. \\ Talca, Chile. \\ ${ }^{3}$ Facultad de Ciencias Agrarias, Universidad de Talca, 2 Norte 685. Talca, Chile.
}

\begin{abstract}
A.A. Cerda, L.Y. García, S. Ortega-Farías, and Á.M. Ubilla. 2012. Consumer preferences and willingness to pay for organic apples. Cien. Inv. Agr. 39(1): 47-59. This study provides marketing data regarding consumer preferences and willingness to pay for organic agricultural products in Chile. The main objectives of this study were to assess consumer willingness to pay for organic apples and to determine the main attributes that consumers look for when purchasing apples. The methodology applied to reach the first objective was the contingent valuation method using a logistic probability function and a single-bound dichotomous choice format. Additionally, this study estimates the marginal willingness to pay (WTP) of consumers for organic apples by using conjoint analysis with ranking procedures. This study was performed in the city of Talca, Chile, where a total of 400 individuals from a probability sampling were interviewed. The results of our study show that the estimation of part-worth utilities of each attribute confirms that the Fuji variety, organic method of production, sweet apples and lowest price are the most preferred levels of each attribute. However, an analysis of the relative utility index shows that price and variety are much more important to consumer choice and behavior than the method of production and flavor. Finally, our study shows a positive willingness to pay an additional 130 Chilean pesos per kilogram for organic apples and a greater preference for apples produced organically than by conventional methods. These results provide important information about market opportunities as well as policy implementation regarding the production of organic agricultural products.
\end{abstract}

Key words: Apple attributes, conjoint analysis, contingent valuation, willingness to pay.

\section{Introduction}

According to the Office of Agricultural Research and Policy (ODEPA, 2008), 30,443 ha were certified as organic, of which 1,052 ha were used to

Received January 10, 2010. Accepted August 29, 2011. Corresponding author: acerda@utalca.cl cultivate apples during the 2007-2008 production period in Chile. These data are based on information provided by organic product certification firms. Given that organic products are recognized as safe, their consumption is growing around the world and is expected to grow in Chile (ODEPA, 2007). Increasing awareness among governments and consumers about product quality and 
pesticide-related food safety has generated a need for studies that address these issues.

There is little information about consumer preferences and their willingness to pay (WTP) for organic agricultural products in Chile despite the large number of studies in developed countries on organic agricultural products (Nadezha and Mazzocco, 2008; Aizaki and Sato, 2007; Silva et al., 2007; Nakaweesa, 2006; Govindasamy and Italia, 1999; Roosen et al., 1998). One of the most important issues in consumer research is to determine consumer preferences so that producers can adapt or generate new products accordingly. Additionally, the value created by introducing new attributes is desirable for companies seeking to be competitive in global and local markets. For example, many companies are obligated to use less toxic production processes to reduce environmental damage to trade in certain markets.

The literature related to measuring the WTP for quality and healthy food products, particularly related to contamination of fruits and vegetables by pesticides, is considerable. For example, studies have shown that most consumers in the United States have a strong risk aversion to pesticide residues on fruit and vegetables (Govindasamy and Italia, 1999) and are therefore willing to pay a premium price for these types of products. Roosenet al. (1998) studied the valuation of implementing a restriction on pesticides used on apples utilizing an auction as an experimental design. In this study, the WTP for apples not treated by a particular pesticide was between US\$ 0.20 and US\$ 0.34 per pound. Baker (1999) used conjoint analysis in different market segments corresponding to consumers concerned about the safety of apples. Loureiro et al. (2002) assessed the mean WTP for eco-labeled apples using a double-bounded logic model and found the value to be very small, around US\$ 0.05. Loureiro et al. (2001) and Loureiro and Hine (2002) estimated preferences and the WTP for organic products. Govindasamy and
Italia (1998) compared the consumer response to traditional production systems and integrated production systems, finding that young people with higher incomes had a greater probability of paying a higher price for products coming from an integrated system of production. Gil et al. (2000) estimated the WTP for food attributes in Spain using the contingent valuation method. Travisi and Nijkamp (2004) combined two stated preference methods, the conjoint choice experiment and the contingent valuation, to estimate the value of reducing the multiple impacts of pesticides. This study showed a positive WTP. Cerda et al. (2010) estimated the WTP using conjoint analysis for organic wine in the Maule Region of Chile and found that the consumer WTP was close to zero. Even though some studies have shown a very low consumer WTP, several studies have shown the consumer WTP at higher prices for food products when these products have some specific attributes (Padilla et al., 2007; Sanchez and Gil, 1998; Sanchez et al., 2001).

In Chile, few studies have been carried out to analyze consumer preferences and WTP for agricultural products. To provide market information about environmentally friendly agricultural products, this study seeks to generate useful information for apple producers by analyzing the potential of organic products. The WTP calculations can help apple producers to perform a cost-benefit analysis for organic apples for the local market.

The main objectives of this study are as follows: i) to assess consumer willingness to pay for organic apples and ii) to determine the main attributes that the apple consumers look for when purchasing apples. We have applied the contingent valuation method using a logistic probability function and a single-bound dichotomous choice format question. Additionally, this study estimates the consumer WTP for organic apples by using conjoint analysis with ranking procedures. 


\section{Materials and methods}

\section{Methods for analyzing preferences and WTP}

The main methods found in the literature for analyzing preference and calculating WTP estimates are contingent valuation (CV), conjoint analysis (CA) and experimental auction (Sanchez et al., 2001; Umbergeret al. 2002; Nakaweesa, 2006). The first two methods are hypothetical valuation methods that utilize survey responses. Experimental auction is a traditional experimental design where the researcher interacts with the respondents to determine a price for a given product or attribute. The advantages and disadvantages of each method can be found in Nalley (2004) and Lusk and Hudson (2004). Given that the auction method typically requires interaction with a tangible good and actual money exchange (Boever, 2006), which was not feasible in this study, contingent valuation and conjoint analysis methods are used. It is important to mention that the CA method complements the $\mathrm{CV}$ method because it enables the breakdown of the stated individual utility into different attributes. Among these attributes is the price attribute, which permits a ranking of the preferences and assigns an economic value to different attributes.

Therefore, we mainly utilize the CV method to estimate the WTP for organic apples and the CA method to estimate the relative importance of the attributes of the apples. Moreover, we estimate the marginal willingness to pay using the CA method.

\section{Conjoint analysis}

$\mathrm{CA}$ is a multivariate method used to find the preferences of respondents for certain products and services (Hair et al., 1999), and it is important to businesses that are evaluating new product or service attributes (Green and Srinivasan, 1978).
CA is consistent with Lancaster's theory of utility maximization, where consumers demand attributes from a given product (Lancaster, 1971; Lusk and Hudson, 2004). The first paper on the applicability of CA to consumers was published by Green and Rao (1971). Since then, CA has been widely applied in market analysis. The CA method is based on the idea that consumers assess the value of a product by combining the different amounts of value provided by each attribute. Thus, it is possible to elicit consumer preferences regarding the attributes of modified food characteristics, in this case organic products, among others. In general, this can be expressed as $U=U(Z)$, where $Z_{t}$ is a vector of the attribute value for the alternative $t$ from the choice set that the consumer is considering buying (Telser and Zweifel, 2000). There are three main elicitation techniques: ranking (respondents rank alternative bundles from least favorite to most favorite), rating (respondents rate alternative bundles given a scale), and discrete choice (respondents are allowed to choose only one option). The first two elicitation techniques were used in this study. Ranking responses ostensibly provides more information than a single choice elicitation technique because it provides information for all profiles. A rating scale requires respondents to make judgments about the level of utility associated with each profile and assumes that this judgment directly transfers utility to the rating scale (Champ, et al. 2003). One limitation of a rating scale is that it does not provide information about choice.

CA implies the assumptions that the choice behavior of consumers is governed by the maximization of utility (Jaeger et al., 2001). To determine the total utility, the additive model (Green and Srinivasan, 1978; Steenkamp, 1987) is commonly used. Considering the four attributes (price, production method, flavor and variety) that are evaluated in this study (Table 1), the econometric representation of the additive utility model is expressed as follows: 
Table 1. Attributes and levels for the conjoint analysis.

\begin{tabular}{lc}
\hline Attribute & Attribute level \\
\hline & $\$ 314$ \\
Price $^{1}$ & $\$ 447$ \\
& $\$ 579$ \\
Method of production & Conventional \\
& organic \\
Flavor & Mostly sweet \\
& Mostly sour \\
Variety & Royal Gala \\
& Fuji \\
\hline
\end{tabular}

${ }^{1}$ Chilean pesos.

$R_{p}=\beta_{0}+\sum_{i=1}^{3} \beta_{1 i} D_{1 i}+\sum_{j=1}^{2} \beta_{2 j} D_{2 j}+\sum_{k=1}^{2} \beta_{3 k} D_{3 k}+\sum_{l=1}^{3} \beta_{4 l} D_{4 l}+\varepsilon_{i}$ where $R_{p}$ represents the independent variable measured by ranking from 1 to 9 the nine product profiles, and $\beta_{1 i}, \beta_{2 j}, \beta_{3 k}, \beta_{4 l}$ are the coefficients associated with the characteristics of each attribute, $i=$ price (three), $j=$ system of production (non-organic and organic), $k=$ flavor (mostly sweet and mostly sour), and l=variety (Granny Smith, Royal Gala, Fuji), while $\mathcal{E}_{i}$ is the error term.

The estimations were performed using the ordinary least squares method by the SPSS, Inc. (2006) conjoint routine. The marginal WTP (MWTP) for each attribute can be calculated as the ratio between the negative of the coefficients of each attribute and the price attribute (Gan and Luzar, 1993). Therefore, the MWTP of organic apples is calculated as $M W T P=-\left[\right.$ Organic apple utility $\left./ \beta_{1}\right]$. Additionally, CA enables the calculation of how influential each attribute is in the utility of the consumer (Green and Wind, 1975). The relative utility of each attribute is calculated according to Halbrendtet al. (1995). The importance of each attribute is estimated as follows:

Utility Range $e_{i}=\left|\operatorname{má} x\left(\beta_{i j}\right)-\min \left(\beta_{i j}\right)\right| \quad \forall i=1, \ldots, I \quad \forall j=1, \ldots, k_{i}$

because each attribute will increase in importance as the difference in absolute value between the highest and lowest part-worth utility grows (Pedretet al., 2000). Therefore, the relative im- portance of each attribute is calculated by the following expression:

$R I_{i}=100 x$ [Utility Range I/ $\Sigma$ Ranges of all attributes].

\section{Construction of attribute profile}

The product used in this study is the apple, a general consumption product and the third-largest organic crop in the country, according to ODEPA (2008). The attributes selected to carry out this study are obtained from an exploratory stage in which interviewees chose their top four preferences from a list of main attributes of apples. The list is constructed on the basis of personal interviews and the literature. The selected attributes are price, variety, flavor and method of production. The levels and characteristics of each attribute are presented in Table 1. The lowest price for the average per-kilogram price of apples is at the farmer's market, the highest average price is at the supermarket, and the middle price is the average of both of these prices. One of the steps in a CA is to create combinations of factor levels that are represented as product profiles to the subjects. A small number of attributes and several levels for each attribute would lead to an unmanageable number of potential product profiles; therefore, it was necessary to generate a representative subset known as an orthogonal design. In this case, a total of 36 hypothetically possible combinations or product profiles $(3 \times 2 \times 2 \times 3)$ can observed from the main attributes and their respective levels. This number is considered to be too many combinations for an individual to manage. Using a computer program (SPSS 10), we generate a set of nine profiles or cards that are in the final interviews with respondents (Table 2).

\section{Contingent valuation}

$\mathrm{CV}$ is widely used for valuing environmental programs because of its ability to estimate WTP due to changes in environmental amenities and 
Table 2. Orthogonal design for apple profiles.

\begin{tabular}{lcccc}
\hline Card & Price & Flavor & Variety & System of Production \\
\hline 1 & 579 & Mostly sour & Fuji & Non-organic \\
2 & 579 & Mostly sweet & Royal Gala & Organic \\
3 & 447 & Mostly sweet & Fuji & Organic \\
4 & 447 & Mostly sweet & Granny Smith & Non-organic \\
5 & 447 & Mostly sour & Royal Gala & Non-organic \\
6 & 314 & Mostly sweet & Fuji & Non-organic \\
7 & 314 & Mostly sweet & Royal Gala & Non-organic \\
8 & 579 & Mostly sweet & Granny Smith & Non-organic \\
9 & 314 & Mostly sour & Granny Smith & Organic \\
\hline
\end{tabular}

services, mainly for public goods or non-market goods, by hypothetical markets (Cerda et al., 2007; Boyle and Bishop, 1998). However, CV can also be used to estimate WTP for changes in food attributes (Maynard and Franklin, 2003; Campiche et al., 2004). It has also has been used for pesticide-free fruits and vegetables (Boccaletti and Nardella, 2000) and organic products (Gil et al., 2000).

The model applied in this study is based on the Utility Difference Model (Hanemann, 1984). The utility function is defined as:

$u_{j}=v_{j}\left(P, I ; q_{j}\right)+\varepsilon_{j} ;$

where $j=0$ represents the initial situation (without a change in the good characteristics), $j=1$ is thefinal situation (the case with organic apples), $P$ is price, $I$ is Income, $q$ represents the apple attribute (organic and non-organic) and $\mathcal{E}_{j}$ is the random error.

Individuals who want to consume organic apples must pay an additional amount of money, where $t$ represents different values offered to different individuals, called the bid vector. Therefore, the probability of paying for an organic apple is given by:

$\operatorname{Pr}($ yes $)=\operatorname{Pr}\left[v_{1}\left(P, I-b_{t} ; q_{1}\right)+\varepsilon_{1}>v_{0}\left(P, I ; q_{0}\right)+\varepsilon_{0}\right]$, or alternatively,

$\operatorname{Pr}($ yes $)=\operatorname{Pr}(\Delta v>\eta)=F_{\eta}(\Delta v)$

where $\Delta v \equiv v_{1}\left(P, I-b_{t} ; q_{1}\right)-v_{0}\left(P, I ; q_{0}\right)+\eta$ and $\eta \equiv \varepsilon_{0}-\varepsilon_{1} \cdot F_{\eta}$ represent the cumulative distribu- tion function of $\eta$, which is assumed to be a logistic probability function expressed as $G(b)=$ $[1+\exp (\Delta v)]^{-1}$.

This logistic model is estimated using the maximum likelihood method (Capps and Cramer, 1985) with the CVM Program (Cooper and Hellerstein, 1994), which produces a logistic calculation for a dichotomous choice contingent valuation method specifically using the method of scoring (Judge et al., 1988). A linear utility function is assumed, and the difference with and without changes in apple attributes can be expressed as $\Delta V=\alpha-\beta b_{t}$. Typically, the expected mean of WTP is calculated as the ratio of $\alpha / \beta$ (unrestricted Hanemann measure). In this study, we also calculate the restricted mean of WTP with the expression $\ln (1+\exp (\alpha)) / \beta$ because it is consistent with theoretical constraints (Lee and Mjelde, 2007). Additionally, an expanded model and the WTP of consumers were estimated by adding the income variable as an explicative variable, as suggested by Cooper and Hellerstein (1994) and following the procedure of Cerda et al. (2010) to estimate the WTP.

The optimal bid vector $\left(b_{t}\right)$ is obtained using the recommendation of Cooper (1993), and a preliminary survey of 100 individuals were asked an open question about their WTP for organic apples. After describing the characteristics of organic apples, the individuals were asked the contingent question, "How much are you willing to pay 'additionally' for a kilogram of organic apples compared to non-organic apples?" The 
bid distribution with equal area bid selection (DWEABS) routine (Cooper, 1993) is applied to this data. This is an iterative technique for finding the mean square error, minimizing sample design for a dichotomous choice contingent valuation model survey. In addition, the DWEABS procedure generated the optimal sample associated with each optimal bid value that minimizes the mean square error of the welfare measures (Table 3). The final survey used these optimal bid values in a single-bound dichotomous choice format question to obtain the WTP.

Table 3. Optimal bid vector of additional willingness to pay for $\mathrm{kg}$ of organic apple and sample size.

\begin{tabular}{lc}
\hline Bid & Sample size \\
\hline 9 & 34 \\
29 & 43 \\
45 & 41 \\
60 & 36 \\
75 & 38 \\
89 & 38 \\
104 & 40 \\
121 & 42 \\
141 & 44 \\
169 & 20 \\
Total & 378 \\
\hline
\end{tabular}

\section{Research design}

The data analyzed in this study were obtained from in-home, face-to-face surveys applied to apple consumers in Talca, Chile. The surveys (preliminary and final surveys) were applied to individuals 18 years and older and were categorized by socioeconomic segments according to the Chilean National Census (2002). Thus, they were divided into the segments $\mathrm{ABC} 1, \mathrm{C} 2, \mathrm{C} 3$, $\mathrm{D}$ and $\mathrm{E}$ (high, middle high, middle low and low income, respectively), from the highest income to the lowest, with the following sample percentages: $4.7,14.5,23.8,40.4$ and $16.6 \%$. It is assumed that most of the population consumes apples, as was observed in the preliminary survey, and a probabilistic sampling was estimated with an error of $4.9 \%$ maximum variance and a confidence level of $95 \%$.

The first part of this study is exploratory. The relevant variables are identified through a bibliography review and personal interviews with 100 individuals to obtain the most important attributes and characteristics for apple consumers and the initial bid value of the WTP through an open-ended format (individual direct response of WTP), which represents the maximum price that each individual is willing to pay for a kilogram of organic apples. The preliminary survey used for the personal interviews included questions to identify preferences and the WTP for regular and organic apples.

With this information, a final survey is constructed that included the relevant questions for applying the conjoint and contingent valuation methods. Prior to application of the final survey, a pilot survey is applied to verify that the instrument are understandable to the interview subjects. The final survey is applied by three researchers to 400 individuals in face-toface interviews between June 27 and July 3, 2009.

\section{Results}

\section{Sample description}

This study used 378 valid interviews from a total of 400. Twenty-two surveys were discarded because they were incomplete. Table 4 presents a summary of the sample characteristics. The socioeconomic segments were grouped into three levels: low income $(\mathrm{E}+\mathrm{D})$, medium income $(\mathrm{C} 2$ $+\mathrm{C} 3)$ and high income (ABC1).

\section{Conjoint analysis and consumer preferences for organic apples}

The internal and predictive validity of the ranking model was estimated by Kendall's tau statistic, 
Table 4. Sample description.

\begin{tabular}{lc}
\hline Variable & Percentage \\
\hline Gender & 54 \\
Female & 46 \\
Male & \\
Age & 26 \\
Between 18 and 34 & 61 \\
Between 35 and 54 & 14 \\
Older than 55 & \\
Family Income (Chilean pesos) & \\
Less than \$399.999 & 76 \\
Between $\$ 400.000$ and \$1.699.999 & 619 \\
More than \$1,700,000 & 6 \\
Education & \\
Srimary Education & \\
\hline
\end{tabular}

which provides measures of the correlation between the observed and estimated preferences (Hair et al., 1999). Kendall's tau statistic shows that there is a strong correlation between the observed preferences and those estimated by both models, which suggests a high predictive validity of the models given the value obtained for this statistic and their respective $p$ (Table 5).

Table 5 shows the utility (part-worth) scores for each factor level. Higher utility values indicate greater preference; therefore, the Fuji variety, organic method of production, sweet apples and the lowest price are the most preferred combination of attribute characteristics to the consumers. The inverse relationship between price level and utility also shows the consistency of the models with reality.
Table 5. Conjoint analysis estimations of utility for ranking.

\begin{tabular}{lcc}
\hline Attribute & Level & Utility ranking model \\
\hline Flavor & Mostly sweet & 0.337 \\
& Mostly sour & -0.337 \\
Variety & Royal Gala & -0.047 \\
& Granny Smith & -0.502 \\
& Fuji & 0.549 \\
Price & 314 & -4.495 \\
& 447 & -6.399 \\
& 579 & -8.289 \\
Method of Production & Conventional & -0.865 \\
Constant & Organic & 0.865 \\
Price Coefficient & & 11.571 \\
Pearson's Rho statistic & & -0.014 \\
Kendall's tau statistic & & $0.997^{1}$ \\
\hline P $=0.000,{ }^{2} \mathrm{P}=0.0001$. & & $0.873^{2}$ \\
\hline
\end{tabular}

Given that preferences are usually expected to be linearly related to price, a linear relationship for preferences was assumed. For example, the predicted utility for the lowest price of $\$ 314$ was listed as -4.495 for the ranking case in the utilities table. This is the value of the price level, $\$ 314$, multiplied by the price coefficient, -0.014 (utility/\$). The presence of organic apples implies a higher utility level with respect to the conventional method of production, as anticipated.

The relative importance index $(R I)$ was computed by taking the utility range for each factor separately and dividing by the sum of the utility ranges for all factors. Table 6 presents the relative utility of each attribute. The method of production occupies third place, indicating that price and variety are much more important in determining consumer choice behavior despite the fact that individuals are willing to pay an additional amount for a kilogram of organic apples. 
Table 6. Relative importance of attributes for the ranking model.

\begin{tabular}{lc}
\hline Variable & Percentage \\
\hline Price & 44.63 \\
Variety & 24.07 \\
$\begin{array}{l}\text { Method of } \\
\text { production }\end{array}$ & 20.56 \\
Flavor & 10.75 \\
\hline
\end{tabular}

Contingent valuation estimation for a kilogram of organic apples

Using the maximum likelihood procedure, the coefficients of the CV logistic model were estimated after five iterations (Judge et al., 1988). The confidence intervals around the welfare meanmeasure were obtained using the Krinsky and Robb approach (Park et al., 1991) and Cameron's approach (Cameron, 1991). These approaches suggest that the methods for evaluating welfare measures for non-market resources should examine not only differences in mean willingness-to-pay measures but also the confidence intervals for the point estimates of WTP.

The model is significant with a chi-squared value of 58 and the coefficients required to estimate WTP (Table 7). Additionally, the sign of the bid value variable, which represents the additional willingness to pay for a kilogram of organic apples, is consistent with the theory that the consumer probability of paying a premium price for organic apples is inversely related to the bid value. The expanded model estimation also shows that the income level positively affects the probability of WTP, as is expected from theoretical considerations. According to conventional criteria, the estimate coefficients and the model are considered to be statistically significant.

\section{Willingness to pay for organic apples}

In general, this study shows through both $\mathrm{CV}$ and $\mathrm{CA}$ that the individuals interviewed have a positive
Table 7. Contingent valuation model estimation.

\begin{tabular}{lcc}
\hline Variables & $\begin{array}{c}\text { Coefficients } \\
\text { traditional } \\
\text { model }\end{array}$ & $\begin{array}{c}\text { Coefficients } \\
\text { expanded model }\end{array}$ \\
\hline & $2.8355^{1}$ & $2.7101^{1}$ \\
& $(0.3218)$ & $(0.3315)$ \\
Bid = b & $-0.02111^{1}$ & $-0.2305^{1}$ \\
Ing1 & $(0.0030)$ & $(0.03237)$ \\
& - & $1.3854^{2}$ \\
Ing2 & - & $(0.3939)$ \\
Log likelihood & -196.0196 & -183.6162 \\
Chi-squared test & $58.4070^{1}$ & $83.2140^{1}$ \\
\hline
\end{tabular}

${ }^{1} \mathrm{P}=0.0001,{ }^{2} \mathrm{P}=0.0005,{ }^{3} \mathrm{P}=0.0116$. Between parenthesis standard error.

Ing1=family income between $\$ 400,000$ and $\$ 1,699,999$; Ing2=family income greater than $\$ 1,700,000$.

Critical Chi-squared $=39.67$.

WTP for organic apples, which is consistent with previous studies in other countries (Baker, 1999; Govindasamy and Italia, 1999; Roosen et al. 1998; Loureiro et al., 2002). Additionally, the results show a positive preference among Chilean consumers for organic apples.

Furthermore, the point-restricted and unrestricted consumer WTP means are 137 and 134 Chilean pesos, respectively (Table 8). Following Krinsky and Robb, consumers have a positive probability of paying between 119 to 167 pesos (US\$ 0.20 to US\$ 0.32) more for organic apples with the confidence interval construction at $99 \%$ of confidence for each kilogram of apples. The value found in our study using CV is quite similar to the value, in current monetary terms, found by Roosen et al. (1998) when using an auction procedure to calculate WTP for organic apples.

It was obtained the negative ratio between the utility of organic apples and the price coefficient and the MWTP was calculated for the ranking model (CLP61.78 $=-0.865$ utility/-0.014 utility/\$). These results indicate that consumers would be willing to pay approximately 61 pesos more for a kilogram of organic apples. 
Table 8. Willingness-to-pay estimates from contingent valuation and conjoint analysis.

\begin{tabular}{ccccc}
\hline & \multicolumn{2}{c}{ Contingent valuation } & & Conjoint analysis \\
\cline { 2 - 2 } & traditional Hanemann model & Expended model & & ranking model \\
\hline WTP $(\$)$ & $136.9696^{1}$ & $137.2210^{1}$ & \\
& $134.2691^{2}$ & $135.3461^{2}$ & \\
\hline
\end{tabular}

${ }^{1}$ Restricted mean WTP. ${ }^{2}$ Unrestricted mean WTP. ${ }^{3}$ Marginal WTP.

\section{Discussion}

The findings suggest that the CV WTP values are higher than the CA WTP values. This difference is partly because the CV WTP represents the mean, and the CA WTP represents the marginal value of WTP for organic apples. Additionally, the literature recognizes the advantages and disadvantages of both methods used in our study (Nalley, 2004; Lusk and Hudson, 2004). For example, CA is less focused on specific attributes, in this case organic apples, while $\mathrm{CV}$ does focus on specific attributes. Some authors state that difference may be due to the possible occurrence of hypothetical bias in CV (Loomis et al., 1997; Cummings et al., 1995; Kanninen, 1995). However, this study takes into consideration the suggestions of Arrow et al. (1993) for applying and obtaining valid and reliable estimates using the CV method, such as the consideration of substitutes and budget restrictions, among other issues that were considered in the survey.

Additionally, given the sample design, there is an important concentration of respondents (77\%) with income below 400,000 Chilean pesos, which may reduce the consumer WTP and consequently the profitability of organic products. Therefore, further research regarding this type of product should focus on socioeconomic segments where there is likely to be a higher consumer WTP, as recognized in the literature for typical goods and services.

Estimation of the part-worth utilities of each attribute confirms that the Fuji variety, organic method of production, sweet apples and the lowest price are the most preferred characteristics of each attribute. However, an analysis of the relative utility index shows that price and variety are much more important for predicting consumer choice behavior than production method and flavor.

Finally, our study showed a positive willingness to purchase organic apples and consumer preference for apples produced organically relative to those produced using conventional methods. These results may provide important information about product attributes to agribusiness management as a way to identify new market segments.

\title{
Resumen
}

\begin{abstract}
A.A. Cerda, L.Y. García, S. Ortega-Farías y Á.M. Ubilla. 2012. Preferencias y disposición a pagar por manzanas orgánicas. Cien. Inv. Agr. 39(1): 47-59. Este estudio provee información de comercialización, con respecto a las preferencias y disposición a pagar por manzanas orgánicas. Específicamente, los objetivos de este estudio fueron determinar la disposición a pagar de los consumidores por manzanas orgánicas y determinar los principales atributos que ellos buscan en las manzanas; fue realizado en la región de Maule de Chile (ciudad de Talca), en donde fueron entrevistados con un total de 400 individuos, obtenidos de una muestra probabilística. El primer objetivo fue alcanzado, aplicando un método de valoración contingente, usando una función logística, con un formato dicotómico simple de elección. Además, este
\end{abstract}


estudio también determina y compara la disposición a pagar marginal de los consumidores para las manzanas orgánicas, usando análisis conjunto, con procedimientos ordenación y calificación. El segundo objetivo es logrado usando análisis conjunto. Los resultados muestran que la variedad Fuji, el método orgánico de producción, las manzanas dulces y el precio bajo son preferidos. Aunque, analizando el índice de utilidad relativo, muestra que el precio y la variedad son más importantes en la elección y comportamiento de los consumidores, que el método de producción y el sabor. Finalmente, el estudio muestra que los consumidores tienen una disposición a pagar adicional por kg de manzanas orgánicas de alrededor de 130 pesos chilenos. Estos resultados proporcionan información importante sobre los atributos deseados a los productores de manzanas como manera de identificar nuevos segmentos de mercado.

Palabras clave: Análisis conjunto, atributos de manzanas, disposición a pagar, valoración contingente.

\section{References}

Aizaki, H., and N. Sato. 2007. Consumers' valuation of good agricultural practice by using contingent valuation and contingent ranking methods: A case study of Miyagi prefecture, Japan. Agricultural Information Research 16 (3): 150-157.

Arrow, K., R. Solow, P. Portney, E. Leamer, R. Radmer, H. Schuman. 1993 Report of the NOAA Panel on contingent valuation. Federal Register.

Baker, G.A. 1999. Consumer preferences for food safety attributes in fresh apples: market segments, consumer characteristics, and marketing opportunities. Journal of Agricultural and Resource Economics 24: 80-97.

Boccaletti, S., and M. Nardella. 2000. Consumer willingness to pay for pesticide-free fresh fruit and vegetables in Italy. International Food and Agribusiness Management Review 3: 297-310.

Boever, B. 2006.Analysis of U.S. aquacultural producer preferences for genetic improvement and cryopreservation. Graduate Faculty of the Louisiana State University and Agricultural and Mechanical College in partial fulfillment of the requirements for the degree of Master of Science, Louisiana, United States. 199 pp.

Boyle, K., and R. Bishop. 1998. Welfare measurements using contingent valuation: a comparison of techniques. American Journal of Agricultural Economics 70: 20-28.
Cameron, T. 1991. Interval estimates of non-market resource values from referendum contingent valuation surveys. Land Economics 67: 413-21.

Campiche, J., R. Holcomb, and C. Ward. 2004. Impacts of consumer characteristics and perceptions on willingness to pay for natural beef in the southern plains. Food Technology Research Report P-1006. Oklahoma Food and Agricultural Products Research and Technology Center, Oklahoma State University, Rome, Italy. 160 pp.

Capps, Jr., O., and R. Cramer. 1985. Analysis of food stamp participation using qualitative choice models- American Journal of Agricultural Economics 67: 49-59.

Cerda, A., L. García, A. Bahamondez, and V. Poblete. 2010. Disposición a pagar para mejorar la calidad del aire en Talca, Chile: Comparación entre usuarios y no usuarios de chimeneas a leña. Lecturas de Economía 72: 195-211.

Cerda, A., J. Rojas, and L. García. 2007. Disposición a pagar por un mejoramiento en la calidad ambiental en el Gran Santiago. Lecturas de Economía 67: 143-160.

Cerda, A., M. Torres, and L. García. 2010. Preferencias y disposición a pagar por vinos orgánicos de parte de los consumidores de la región del Maule, Chile. Revista Panorama Socioeconómico 40: 60-71.

Champ, P., K. Boyle, and T. Brown. 2003. A primer on nonmarket valuation. Series Editor I. Bate- 
man. The economics of non-market goods and resources. Kluwer Academic Publisher, Dordrecht, The Netherlands. 592 pp.

Cooper, J. 1993. Optimal bid selection for dichotomous choice contingent valuation surveys. Journal of Environmental Economics and Management 24: 25-40.

Cooper, J., and D. Hellerstein.1994. CVM Software. USDA/ERS/Resources and Technology Division, Washington DC, 20005-4788.

Cummings, R., G. Harrison, and E. Rutström. 1995. Homegrown values and hypothetical surveys: is the dichotomous choice approach incentive compatible? American Economic Review 85: 260-266.

Gan, C., and E. Luzar. 1993. A conjoint analysis in waterfowl hunting in Lousiana. Journal of Agricultural and Applied Economics 25: 36-45.

Gil, J., A. Gracia., and M. Sánchez. 2000. Market segmentation and willingness to pay for organic products in Spain. International Food and Agribusiness Management Review 2: 207-26.

Goodman, S. 2009. An international comparison of retail consumer wine choice International Journal of Wine Business Research 21: 41-49.

Govindasamy, R., and J. Italia. 1999. Predicting willingness-to-pay a premium for organically grown fresh produce. J. Food Distrib. Res. 30: 44-53.

Green, P., and Y. Wind. 1975. New way to measure consumers' judgments. Harvard Business Review 53: 107-117.

Green, P., and V. Srinivasan. 1978. Conjoint analysis in consumer research: issues and outlook. J. Cons. Res. 5: 103-123.

Green, P., and V. Srinivasan. 1990. Conjoint analysis in marketing: new developments with implications for research and practice. Journal of Marketing 4: 3-19.

Green. P., and V. Rao. 1971. Conjoint measurement for quantify judgment data. J. Market Res. 8: 355-363.

Hair, J., R. Anderson, R. Tathan, and W. Black.1999. Análisis Multivariante. Quinta Edición. Prenticehall. Iberia, Madrid, España. 822 pp.

Halbrendt, C., Q. Wang, C. Fraiz, and L. O'Dierno. 1995. Marketing problems and opportunities in
Mid Atlantic sea food retailing. American Journal of Agricultural Economics 77: 1313-1318.

Hanemann, W.M. 1984. Welfare evaluation in contingent valuation experiments with discrete response. American Journal of Agricultural Economics 66: 332-341.

Hanemann, W.M. 1991. Willingness to pay and willingness to accept: How much can they differ? American Economic Review 81: 635-647.

Jaeger, S., D. Hedderley, and H. Mactie. 2001. Methodological issues in conjoint analysis: A case study. European Journal of Marketing 35: 11-12.

Jekanowski, M., D. Williams II, and W. Schiek. 2000. Consumers' willingness to purchase locally produced agricultural products: an analysis of an Indiana survey. Agricultural and Resource Economics Review 29(8): 43-53.

Judge, G., R. Hill, R. Carter, W. Griffiths, H. Lutkepohl, and L.Tsoung-Chao. 1988. Introduction to the Theory and Practice of Econometrics, Publisher John Wiley \& Sons, New York, United State. 1064 pp.

Kanninen, B. 1995.Bias in discrete response contingent valuation. Journal of Environmental Economics and Management 28: 114-125.

Krinsky, I., and A. Robb.1986. On approximating the statistical properties of elasticities. Rev. Econ. and Statistic. 68: 715-719.

Lancaster, K. 1971. Consumer demand: A new Approach. Columbia University Press, New York, United States. 177 pp. Lee, C-K., and J. Mjelde. 2007. Valuation of ecotourism resources using a contingent valuation method: The case of the Korean DMZ. Ecological Economics 63: 511-520.

Lesschaeve, I. 2007. Sensory evaluation of wine and commercial realities: Review of current practices and perspectives. Am. J. Enol. Vitic. 58: 252-258.

Lohr, L. 1998. Implications of organic certification for market structure and trade. American Journal of Agricultural Economics 80: 1125-1129.

Loomis, J., T. Brown, B. Lucero, and G. Peterson. 1997. Evaluating the validity of the dichotomous choice question format in contingent valuation. Environmental \& Resource Economics. European Association of Environmental and Resource Economists 10: 109-123. 
Loureiro, M., and S. Hine. 2002. Discovering niche markets: a comparison of consumer willingness to pay for local (Colorado grown), organic, and gmo-free products. Journal of Agricultural and Applied Economics 34(3): 477-487.

Loureiro, M., J. Mccluskey, and R. Mittelhammer. 2002. Will consumers pay a premium for ecolabeled apples? Journal of Consumer Affairs 36: 203-219.

Loureiro, M., L., J. McCluskey, and R. Mittelhammer. 2001. Assessing consumers preferences for organic, eco-labeled and regular Apples. Journal of Agricultural and Resource Economics 26: 404-416.

Lusk J., and D. Hudson. 2004. Willingness-to-pay estimates and their relevance to agribusiness decision making. Review of Agricultural Economics 26: 152-169.

Lusk, J.L. 2003. Effect of cheap talk on consumer willingness-to-pay for golden rice. American Journal of Agricultural Economics 85: 840-856.

Maynard, L., and S. Franklin. 2003. Functional foods as a value-added strategy: the commercial potential of 'cancer-fighting' dairy products. Review of Agricultural Economics, Fall-Winter 25: 316331.

Misra, S., C. Huang, and S. Ott. 1991. Consumer willingness to pay for pesticide-free fresh produce. Western Journal of Agricultural Economics 16: 218-27.

Nadezhda, K., and M. Mazzocco. 2008. Consumer preferences and trade-offs for locally grown and genetically modified apples: a conjoint analysis approach. International Food and Agribusiness Management Review 11(4): 31 -53.

Nakaweesa, M. 2006.Analysis of consumer attitudes and their willingness to pay for functional foods. Louisiana State University and Agricultural and Mechanical Collegian partial fulfillment of the requirements for the degree of Master of Science. Louisiana, United States. 147 pp.

Nalley, L. 2004. Credence attributes, consumer valuation, and endowment effects in auctions: the case of sweet potatoes. M.S. Thesis. Department of Agricultural Economics, Mississippi State University, Mississippi, United States.
ODEPA. 2007. Base de datos de comercio exterior. Oficina de Estudios y Políticas Agrarias (ODEPA). Available online at: http://www.odepa.cl (Website accessed: October 20, 2008).

ODEPA 2008. Base de Datos de comercio exterior. Oficina de Estudios y Políticas Agrarias (ODEPA). Available online at: http://www.odepa.cl (Website accessed: October 20, 2008).

Padilla, C., P. Villalobos, A. Spiller, and G. Henry. 2007. Preferencias y disposición del consumidor a pagar por un sello de calidad certificada para productos de alimentos de origen campesino. Agric. Téc. 67:300-308.

Park, T., J. Loomis, and M. Creel. 1991. Confidence intervals for evaluating benefits estimates from dichotomous choice contingent valuation studies. Land Economic 67: 64-73.

Roosen, J., J. Fox, D. Hennessy, and A. Schreiber. 1998. Consumers' valuation of insecticide use restrictions: an application to apples. Journal of Agricultural and Resource Economics 23: 367384.

Sánchez, G., I. Grande, J. Gil., and A. Gracia. 2001. Diferencias entre los segmentos del mercado en la disposición a pagar por un alimento ecológico: valoración contingente y análisis conjunto. Estudios Agrosociales y Pesqueros 190: 141-163.

Sánchez, G., and G. Gil. 1998. Evaluación del potencial de mercado de los productos de agricultura ecológica. Rev. Esp. Invest. Marketing 2: 135150.

Silva, A., R. Nayga, B. Campbell., and J. Park. 2007. On the use of valuation mechanisms to measure consumers' willingness to pay for novel products: A comparison of hypothetical and non-hypothetical Values. International Food and Agribusiness Management Review 10: 165-180.

SPSS, Inc. 2006. SPSS Categories Version 10.0, Chicago.

Steenkamp, J. 1987. Conjoint measurement in ham quality evaluation. Journal of Agricultural Economics 38: 473-480.

Telser, H., and P. Zweifel. 2000. Measuring willingness-to-pay for risk reduction: An application of conjoint analysis, Health Economics 11:129139. Available online at: http://ideas.repec.org/p/ 
soz/wpaper/0003.html (Website accessed October 20, 2008).

Travisi, C., and P. Nijkamp. 2004.Willingness to pay for agricultural environmental safety.Tinbergen Institute Discussion Paper, TI 2004$070 / 3$. The Netherlands. Available online at: http://ideas.repec.org/p/dgr/uvatin/20040070. htmland and http://www.tinbergen.nl/discussionpapers/04070.pdf (Website accessed October 20, 2008).

Umberger, W.J., D.M. Feuz, C.R. Calkins, and K. Killinger-Mann. 2002. U.S. consumer prefer- ence and willingness-to-pay for domestic cornfed beef versus international grass-fed beef measured through an experimental auction. Agribusiness 18: 491-504.

Vásquez, F., A. Cerda, and S. Orrego. 2007. Valoración económica del ambiente. Fundamentos económicos, econométricos y aplicaciones. Thomson Learning. Buenos Aires, Argentina. 368 pp.

Wang, Q., and J. Sun. 2003. Consumer`s preferences and demand for organic food: evidence from a Vermont survey. American Agricultural Economics Association Annual Meeting, Montreal, Canada. p. 12. 
